\title{
Surprise Christmas present for British science
}

AN unexpected Christmas bonus for British science was revealed this week by the Secretary of State for Education and Science, Mrs Shirley Williams, who announced that the country's science budget was to be increased by more than $£ 47$ million over the next four years. More than $70 \%$ of this money is to go to the Science Research Council and the remainder is to be divided between the Agricultural Research Council, the Medical Research Council, and the Natural Environment Research Council. Only the Social Science Research Council budget remains static.

The budget increase represents a significant Cabinet victory for Mrs Williams who has been arguing strongly all year for increases in funds for basic scientific research-which, she said, had suffered too severely at the expense of applied research. Now the science budget is to be increased by $£ 10$ million in 1979-80; $£ 10$ million in $1980-81 ; £ 12$ million in 1981-82 and £15 million in 1982-83. The move will increase next year's budget to $£ 274$ million of which $£ 149.7$ million will go to the SRC.

The increase reflected a change in world opinion which was now swinging back to a more favourable view of basic research, said Sir Frederick Stewart, chairman of the Advisory Board for the Research Councils, the body responsible for dispersing the science budget among the five research councils. He quoted recent developments in the United States and France where there had been increases in

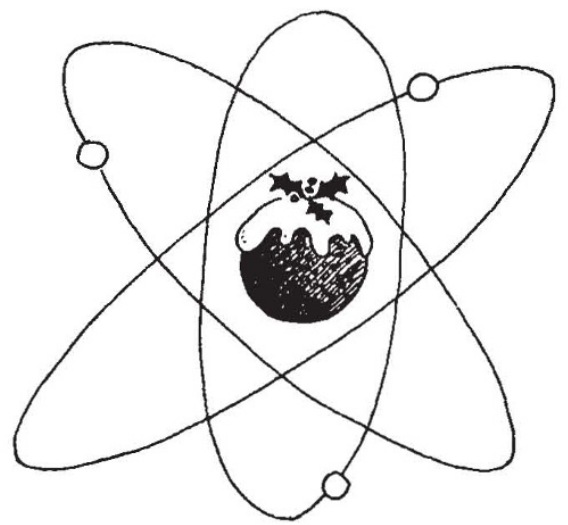

money for fundamental research.

Mrs Williams said Britain had insufficiently recognised the achievements of its basic science which was regarded highly elsewhere in the world. This extra cash would attempt to remedy this and would also be used to create new research positions for able young students who were now suffering severe problems in finding posts.

Predictably the happiest research council chairman was Professor

\section{Research allocations}

$1979-801980-81$ 1981-82 1982-83

\begin{tabular}{|c|c|c|c|c|}
\hline & fm & $\%$ & $\%$ & $\%$ \\
\hline ARC & 24.7 & +1.9 & +1.1 & +1.0 \\
\hline MRC & 46.5 & +1.6 & +0.9 & +1.0 \\
\hline NERC & 31.1 & +2.5 & +1.5 & +1.0 \\
\hline SRC & 149.7 & -1.0 & -0.5 & +1.0 \\
\hline SSRC & 14.8 & 0.0 & 0.0 & 0.0 \\
\hline $\mathrm{BM}(\mathrm{NH})$ & 4.6 & +0.5 & +0.5 & +1.0 \\
\hline \multirow[t]{2}{*}{ Royal Soc } & 2.6 & +1.0 & +1.0 & +1.0 \\
\hline & 274.0 & & & \\
\hline
\end{tabular}

Geoffrey Allen of the SRC who described himself as "delighted" with his cash allocation. Last month he announced at the publication of his council's annual report that the SRC needed only $£ 20-£ 30$ million to carry out a full but realistic programme of research over the next four years. In fact, the budget increase means he will now have slightly more than $£ 30$ million for this programme, of which $£ 4$ million will become available next year.

Initially much of this money will go to restoring the SRC's construction programme to previous levels, including the speedy completion of synchrotron radiation, laser and electron beam lithography facilities at the SRC's laboratories, and also in setting up research programmes in computer and microprocessor technology. It is also hoped that Britain will get a new space programme involving participation in the United State;' MMS re-usable satellite project.

As for the other research councils, it is likely that the extra cash will be used on projects including increased research into cancer and its treatment and also to set up a new unit of environmental epidemiology for the Medical Research Council; to improve geological work in deep drilling and mapping for the Natural Environment Research Council; and to support work for the Agricultural Council which would involve developing crops which could fix their own atmospheric nitrogen.

Robin McKie

\section{Blind man's buff at GMAG}

ON 31 December, the two-year term of office for members of the UK's Genetic Manipulation Advisory Group (GMAG) will come to an end; some members will be leaving and new people appointed in their place. But the criteria used to decide who will stay on and who will leave are a deepening mystery.

The only official information that has been made public about the changes is that Sir William Henderson (until recently Secretary to the Agricultural Research Council) will succeed Sir Gordon Wolstenholme as chairman. A spokesman at the Department of Education and Science told Nature last week that in the interest of "balance and continuity", the four sectors represented on GMAG (science, industry, the unions and the public) would continue to be represented and that not all the members of the existing GMAG would be asked to stand down.
According to John Morris, GMAG secretary at the Medical Research Council, however, that does not mean that "some members who may wish to stay on will not be sacked"

At least one member of the group, Dr J. R. Ravetz, a public interest representative, can testify to this. Three months ago all members of GMAG were sent a letter asking if they wished to continue. Dr Ravetz, a reader in the history and philosophy of science at the University of Leeds, had played a particularly active role in GMAG and did not wish to leave, but was sent a letter asking him to stand down. He was given no reason other than that new appointments "are necessary to ensure the balance and continuity of the group".

However, two of the three other public interest representatives have indicated that they wish to stand down for personal reasons. Continuity in the public interest sector, Ravetz argues, is therefore being carried on the shoulders of the only remaining public representative, John Maddox. $\mathrm{Mr}$ Maddox was unaware that two of the public representatives were leaving voluntarily until contacted by Nature last week.

What then are the criteria used to decide which representatives should be removed, and who is responsible for making these changes? For the union and industry representatives, the situation is clear. They are nominated or recommended to stand down by their respective organisations and these recommendations are generally accepted by the DES. The Trades Union Congress (TUC) has asked to be represented on the new GMAG by its four original representatives and by one new member. The four serving TUC members have been reappointed by the DES, but there is no word yet about 